\title{
Organic Vegetables Quality Arising from the Brazilian Family-Run Farm
}

\author{
Thadia Turon Costa da Silva ${ }^{1,2,3}{ }^{*}$, Verona Borges Ferreiraa ${ }^{2,3}$, Silvia Magalhães Couto ${ }^{2,3}$, \\ Armando Ubirajara Oliveira Sabaa Srur 1,2,3 \\ ${ }^{1}$ Department of Food Technology, Federal Rural University of Rio de Janeiro, Rio de Janeiro, Brazil \\ ${ }^{2}$ Nutrition Institute, Federal University of Rio de Janeiro, Rio de Janeiro, Brazil \\ ${ }^{3}$ Research Group in Fruits and Vegetables Processing, CNPq, UFRJ, Rio de Janeiro, Brazil \\ Email: ${ }^{*}$ thadia@uol.com.br
}

Received 27 May 2014; revised 4 July 2014; accepted 15 July 2014

Copyright (C) 2014 by authors and Scientific Research Publishing Inc.

This work is licensed under the Creative Commons Attribution International License (CC BY).

http://creativecommons.org/licenses/by/4.0/

c) (i) Open Access

\section{Abstract}

The present study has its aim to evaluate the different dimensions of organic vegetables quality from the Brazilian family-run farm, especially the evaluation of composition, antioxidant activity, microbiological characteristics and pesticide residues. There were evaluated carrot, broccoli, kale and white cabbage grown by organic farmers in the highlander region of Rio de Janeiro state. There were determined humidity, lipids grade, total protein content, mineral residues (ashes), soluble and insoluble fibers, soluble solids, total acidity, $\mathrm{pH}$, and pesticide residues. The antioxidant activity was determined using DPPH (2,2-diphenyl-1-picrylhydrazyl) free radical removal. Among the analyzed vegetables, the effectiveness of the antioxidant capacity was obtained, in decreasing order, by broccoli, kale, white cabbage and carrot. According to the microbiological parameter, evaluated vegetables have shown satisfactory sanitary quality. Pesticide residues were not found above the detection limit for both authorized and unauthorized analyzed crops.

\section{Keywords}

Organic Food, Vegetables, Pesticide, Antioxidant Capacity, Food Composition

\section{Introduction}

One of the "Global Aliment Strategy, Physical Activity and Health" recommendations, classified with convincing evidence level by World Health Organization, is to increase consumption of fruits, vegetables and cereals. Currently, it is recommended to consume at least $400 \mathrm{~g}$ of fruits and vegetables a day, which is between $9 \%$ and

"Corresponding author.

How to cite this paper: da Silva, T.T.C., Ferreira, V.B., Couto, S.M. and Srur, A.U.O.S. (2014) Organic Vegetables Quality Arising from the Brazilian Family-Run Farm. Food and Nutrition Sciences, 5, 1538-1543. 
$12 \%$ of total $2000 \mathrm{kcal}$ calories daily diet [1]. In Brazil, according to the dates of the Consumer Expenditure Survey by the Brazilian Institute of Geography and Statistics that was realized between 2008 and 2009 [2], home fruit and vegetables availability was approximately $2.8 \%$ of total calories or one fourth of recommended amount of these aliments consumption. The analysis of personal aliments consumption has shown that less than $10 \%$ of Brazilian population eat recommended amount of fruits and vegetables [3].

The food of vegetable origin is the source of vitamins, minerals, fibers, carbohydrates and bioactive compounds, principally polyphenols, group of phytochemicals recognized as antioxidants that are more abundant in our diet [4]. However, pesticides residues are chemical ingredients that can be found in these aliments and they can be a potential risk to human health, so its evaluation would become necessary. According to the results of pesticide residues monitoring of federal government food, 907 of 3130 analyzed samples in 2009 were considered unsatisfied (29.0\%) [5]. Main irregularities found in these samples were the level of pesticides that was higher than maximum limit of residues in 88 samples, representing $2.8 \%$ of total amount. The pesticide use that was not authorized for the culture in 744 samples, representing $23.8 \%$ of total amount and the combination of two irregularities in the same sample in $2.4 \%$ of total amount [5].

In spite of being produced without pesticides use organic aliments can cause environmental contamination of ground, water or adopted after harvest experiments. At the same time the authors highlight biological dangers for organic vegetables due to the use of organic green manure, animal excrements and handling practices. In this case it becomes necessary to evaluate the quality of organic vegetables arising from family-run agriculture.

The present study has its aim to characterize organic vegetables considering nutritional value, antioxidant activity, microbiological quality and pesticides residues presence. It is expected that represented results of this work contribute for family-run agriculture recognition regarding development and aliment and nutritional security; stimulation for sustainable agriculture production with agroecology upgrading; and the guaranty of income for families of farmers, providing better life quality.

\section{Materials and Methods}

\subsection{Starting Material}

Family-run organic certified farmers were identified by Organic Farmers Associations. The following fresh vegetables have been chosen for offer and consumption analysis: carrot (Daucus carota L.), broccoli (Brassica oleraceae, var. itálica), kale (Brassica oleraceae, var. acephala) and cabbage (Brassica oleraceae, var. capitata). These four types of vegetables were chosen based on Brazilian food consumption data, availability in the local market and the intensive use of pesticides in these conventional crops.

The samples were gathered by accident at the cultivation units in the period from January to March, 2012 and July, 2012, in the beginning, middle and the end of the seedbeds. After picking they were added into polyethylene bags and sent to the laboratory and stored under refrigeration of $5^{\circ} \mathrm{C}$. For pesticides residues quantification the samples were stored under $-16^{\circ} \mathrm{C}$ until the moment of analysis.

\subsection{Macronutrients Determinations}

Humidity, lipids grade, total protein content, mineral residues (ashes), soluble and insoluble fibers, as well as total concentration of soluble solids, total acidity, $\mathrm{pH}$ were determined according to Association of Official Analytical Chemists [6]. The rate of carbohydrates was obtained as a difference between 100 and the sum of the components of hundredth composition part.

\subsection{Antioxidant Activity by the Method of Free Radical Removal DPPH}

The method of DPPH was realized according to the described procedure Rufino et al., Sánchez-Moreno et al., and Brand-Williams, et al. [7]-[9]. There were prepared samples extracts from vegetable in natura, using hydroalcoholic $80 \%$ methanol solution $(\mathrm{v} / \mathrm{v})$ at $70^{\circ} \mathrm{C}$ for 10 minutes; the samples were homogenized and filtered, in repeated operations and afterwards placed in the rotaevaporador at $40^{\circ} \mathrm{C}$ for 15 minutes. 2,2-diphenyl-1-picrylhydrazyl (DPPH) was purchased from from Sigma-Aldrich (St.Louis, MO, USA). All other chemicals and reagents were of analytical quality grade.

In $3.9 \mathrm{~mL}$ of DPPH radical at $100 \mu \mathrm{M}$, solved in $80 \%$ methanol, was added to $0.1 \mathrm{~mL}$ of the sample or control was carefully homogenized and kept in the darkness at the ambient temperature $\left( \pm 25^{\circ} \mathrm{C}\right)$. The absorbance was 
measured at $517 \mathrm{~nm}$ after 15, 30 and 60 minutes $\left(\mathrm{Abs}_{\text {sample}}\right)$. The attempts were realized in triplicate and based on the obtained numbers the percentage of consumed DPPH radical was calculated as it is shown in the Equation (1); the results expressed the DPPH radical capacity of remove/reduce (\%).

$$
\% \text { of consumed DPPH }=100-\{[(\text { Abs sample }- \text { Abs white }) * 100] / \text { Abs control }\}
$$

\subsection{Microbiological Quality}

The study of hygienic and sanitary quality of organic vegetables was realized according to Compendium of Methods for the Microbial Examination of Foods [10], with research of Salmonella sp. presence, coliforms count at $35^{\circ} \mathrm{C}$, coliforms at $45^{\circ} \mathrm{C}$ and Escherichia coli in organic samples of carrot, broccoli, cabbage and kale in natura. Result rendering was according to Brazilian Technical Rules about Microbiological standards for Aliments [11].

\subsection{Pesticides Residues}

Pesticides residues quantification was realized through multiresidual analysis [12] [13]. There were explored pesticides residues belonging to the following chemical groups: organophosphate, pyrethroid, neonicotinoid, alquilenobis (dithiocarbamate), methylcarbamate oxime, strobilurin methylcarbamate benzofuranila isoftalonitrila, triazole, oxazolidinedione, dicarboximide, methyl isothiocyanate, anilinopyrimidine, imidazolyl, carboxamide, dinitroaniline which is making up total 112 active ingredients. The determinations were realized via gaseous chromatography linked with mass spectrometry (GC-MS/MS-Varian-Saturno $2100 \mathrm{~T}$ Ion Trap with Auto Sampler), liquid chromatography linked with mass spectrometry (LC-MS/MS-Waters Acquity/TQD with software Masslinx) and the samples were prepared by QuEChERS method [13]. Found concentrations were expressed in $\mathrm{mg} / \mathrm{kg}$ and compared to maximum residue level for each active ingredient according to Brazilians Residues Monographs established by National Sanitary Surveillance Agency (ANVISA) [14].

\subsection{Statistics Analysis}

All the analytical determinations were performed in triplicates, with estimation of the averages and standard deviations.

\section{Results and Discussions}

The average results of hundredth composition of carrot, broccolis, cabbage and kale are shown on the Table 1 . Studied vegetables are among the highest consumption in Brazil [3] with its nutritional relevance, especially in fibers, vitamins and minerals. The results show prevalence of insoluble fiber portion in all vegetables. The average contents of dietary fiber were 2.64\% (broccolis), 1.95\% (kale), 1.59\% (carrot) and 1.49\% (cabbage), demonstrative results for the advisable consumption for adults of 25 - 30 g/day.

Table 1. Physical, chemical and physic-chemical determination in organic samples of carrot, broccoli, spring greens and cabbage.

\begin{tabular}{|c|c|c|c|c|}
\hline Determinations & Carrot & Broccoli & Kale & Cabbage \\
\hline Humidity (\%) & $90.66 \pm 0.04$ & $84.43 \pm 0.15$ & $90.24 \pm 0.04$ & $93.70 \pm 0.03$ \\
\hline Ashes (\%) & $0.75 \pm 0.00$ & $1.16 \pm 0.02$ & $1.11 \pm 0.01$ & $0.40 \pm 0.02$ \\
\hline Protein (\%) & $1.00 \pm 0.04$ & $2.27 \pm 0.30$ & $2.08 \pm 0.15$ & $0.73 \pm 0.06$ \\
\hline Lipids (\%) & $0.29 \pm 0.05$ & $0.37 \pm 0.01$ & $0.20 \pm 0.00$ & $0.17 \pm 0.00$ \\
\hline Carbohydrate & $7.30 \pm 0.11$ & $11.77 \pm 0.24$ & $6.36 \pm 0.12$ & $5.01 \pm 0.08$ \\
\hline Soluble fiber (\%) & $0.51 \pm 0.01$ & $0.76 \pm 0.14$ & $0.55 \pm 0.01$ & $0.32 \pm 0.03$ \\
\hline Insoluble fiber (\%) & $1.08 \pm 0.09$ & $1.88 \pm 0.04$ & $1.40 \pm 0.00$ & $1.17 \pm 0.12$ \\
\hline Acidity (g NaOH/100g) & $0.03 \pm 0.01$ & $0.12 \pm 0.02$ & $0.05 \pm 0.00$ & $0.01 \pm 0.00$ \\
\hline $\mathrm{pH}$ & $6.60 \pm 0.06$ & $6.43 \pm 0.03$ & $6.16 \pm 0.00$ & $6.52 \pm 0.01$ \\
\hline SST ( ${ }^{\circ}$ Brix) & $8.17 \pm 0.21$ & $12.29 \pm 0.30$ & $4.09 \pm 0.09$ & $7.82 \pm 0.10$ \\
\hline
\end{tabular}


Various researches were taken place to study the difference between food cultivated in organic and conventional system, however there is still difference of opinions. Systematic literature revisions did not show significant differences of nutrients levels, and found differences were not considered nutritionally important [15]-[17]. It is also known that environmental and edaphic factors as temperature, relative air humidity, and sun and rain incidence, besides genotype (plant variety) can meaningfully interfere in nutritional and phytochemical food composition. As well as different plants of the same culture type can differ the nutrients contents according to the type of used fertilizer, pesticides handling, growing conditions, season of the year and other factors. This variability of nutrients contents can also be affected during the stockpiling, transportation or preparation of foodstuffs before arriving to consumer plate. Therefore understanding the factors that affect nutrients variability in vegetable cultures is important for research plan and interpretation that compare nutrients contents of organic and conventional foodstuffs [16].

Among analyzed vegetables, antioxidant capacity effectiveness was obtained, in decreasing order: broccolis $(69.35 \% \pm 5.29 \%)$, kale $(63.20 \% \pm 3.84 \%)$, cabbage $(35.71 \% \pm 3.40 \%)$ and carrot $(20.39 \% \pm 1.13 \%)$. Arbos et al. [18] evaluated antioxidant activity via DPPH method of vegetables arising from organic and conventional cultivation. All analyzed vegetables have demonstrated antioxidant property with variation of intensity, depending on studied sort, extract concentration and cultivation type; it is necessary to stand out that higher activity was found in organic vegetables with consumed DPPH \% of 77.3 for rocket, 77.2 for endive and 72.3 for lettuce.

In the study presented by Faller \& Fialho [4] antioxidant activity, expressed in capacity of radical (\% RSC) removal after 60 minutes reaction with DPPH, was $61.0 \pm 0.06$ for stem and $73.8 \pm 0.03$ for conventional flowers, $79.2 \pm 0.01$ for leaves of organic broccolis and $61.9 \pm 0.10$ for peel and $19.0 \pm 0.28$ for organic carrots pulp. The results indicate the presence of compounds with high antioxidant capacity in studied vegetables. However, the result of carrot antioxidant activity was higher than expected. It is known that carrots are rich in carotenoid that has excellent antioxidant activity; however methanol extraction seems to be less efficient for these compounds. According to Prior et al. [19] carotenoids interfere with the interpretation of DPPH Assay because the test compounds have spectra the overlap DPPH at $515 \mathrm{~nm}$.

Table 2 shows the results of biological analysis of organic carrot, broccoli, kale and cabbage. The presence of Salmonella sp. was not detected in any sample, according to valid legislation. The samples of carrot and broccoli show coliforms contents at $45^{\circ} \mathrm{C}$ and Escherichia coli less than $0.3 \mathrm{NMP} / \mathrm{g}$, as well as samples of cabbage and kale, characterizing reduced contents of these microorganism-indicators. Based on obtained results it is possible to infer, under microbiological parameter, that the evaluated vegetables show satisfactory hygienic-sanitary quality.

Santos \& Monteiro [20] show that organic agriculture is an option for secure food production, but worldwide produced quantity is still not enough to supply population. The authors point out that there is still lack of information describing microbe contamination in organic food. They conclude that studies related to organic food consumption and its implications for human health would fulfill a big gap.

Mukherjee et al. [21] analyzed microbiologically 476 organic and 129 conventional products in the United States in which they were searching the presence of E. coli, Salmonella and E. coli 0157:H7. The results show E. coli detection in $4.6 \%$ of organic certified products and $1.6 \%$ of conventional products, considering that this difference was not significant. The samples have not shown E. coli 0157:H7 presence and only two samples of organic products were observed for Salmonella presence.

It is known that fertilizer type used in the organic production systems has muck as starting material and other animal excrements that can lead to higher microbe quantity and risk of food contamination. However, it also

Table 2. Microbiological evaluation of organic vegetables.

\begin{tabular}{cccccc}
\hline Determinations & Brazilian Standards & Carrot & Broccoli & Kale & Cabbage \\
\hline Search Salmonella SP & Absence in $25 \mathrm{~g}$ & Absence/25 g & Absence/25 g & Absence/25 g & Absence/25 g \\
Coliforms cont. at $35^{\circ} \mathrm{C}$ & No referable & $9.3 \mathrm{MPN} / \mathrm{g}$ & $2.3 \mathrm{MPN} / \mathrm{g}$ & $15 \mathrm{MPN} / \mathrm{g}$ & $1100 \mathrm{MPN} / \mathrm{g}$ \\
Coliforms cont. at $45^{\circ} \mathrm{C}$ & No referable & $<0.3 \mathrm{MPN} / \mathrm{g}$ & $<0.3 \mathrm{MPN} / \mathrm{g}$ & $<0.3 \mathrm{MPN} / \mathrm{g}$ & $<0.3 \mathrm{MPN} / \mathrm{g}$ \\
Escherichia coli cont. & No referable & $<0.3 \mathrm{MPN} / \mathrm{g}$ & $<0.3 \mathrm{MPN} / \mathrm{g}$ & $<0.3 \mathrm{MPN} / \mathrm{g}$ & $<0.3 \mathrm{MPN} / \mathrm{g}$ \\
Aerob. Mesophilic viable Bact. & No referable & $7.5 \times 10^{3} \mathrm{CFU} / \mathrm{g}$ & $4.7 \times 10^{6} \mathrm{CFU} / \mathrm{g}$ & $5.4 \times 10^{5} \mathrm{CFU} / \mathrm{g}$ & $1.2 \times 10^{6} \mathrm{CFU} / \mathrm{g}$ \\
\hline
\end{tabular}


depends on a producer and evaluation institutions of organic conformity, compliance of norms of organic fertilizing use, observed appropriate time of compost, as well as its preparation and handling.

Regardless of scientific evidences about organic vegetables quality, mainly in relation of nutrients contents, it should not be the only one motivation for this food consumption. It is unquestionable that practices of this agriculture type search for socio-environmental sustainability, unlike conventional model, where it is usual in monoculture the use of fertilizers and pesticides that make ground poor, destroy microorganisms and pollute water, affecting animals, plants, human beings and all ecosystem [22] [23]. In this way the conscious and responsible consumer to choose his diet should worry about functional and nutritional quality, in addition to pesticides residues and food contaminant, about farmer's health, about environment preservation and future generations.

Pesticides residues above the detection limit in evaluated organic vegetables were not found. It was observed that for all evaluated active ingredients the results were less than detection limit. Considering residues concentration in food, Jardim \& Caldas [24] discuss how to deal with the samples that did not present detectable/quantifiable levels of analyte, this is when the results are reported less than detection or quantification limit. This question was widely regarded by different authors, it was agreed that selection procedure should be conservative and sufficient to maintain precautions considering toxic substances, but also scientifically justifiable unless there are sufficient evidences to be sure that no pesticides of substances are expected in food. In case of vegetables in question, because they have been cultivated according to organic agriculture rules, the expected results were near zero or pesticides residues were absent.

The study comparing nutritional and toxicological quality of conventional and organic tomatoes carried out by Ferreira et al. [25] has shown that only tomato humidity had significant difference. In pesticides residues of chemical group of ditiocarbamates it was detected $0,01 \mathrm{mg} \cdot \mathrm{kg}^{-1}$ (CS2) in tomato samples cultivated in conventional systems, however it was less than maximum recommended limit of $2.0 \mathrm{mg} \cdot \mathrm{kg}^{-1}$ (CS2) of mancozeb.

One fundamental question in debates about organic agriculture contribution for worldwide agriculture is if it has capacity to produce sufficient to feed the world. The study of systematic revision evaluated 362 articles comparing productivity of organic and convention aliments. The results show that productivity of individual organic cultures crop is approximately $80 \%$ of conventional production, however considerable standards are $21 \%$ [26].

As the food security is unquestionable aliments produced in conventional agriculture present raw material residues that can cause harm to consumer health when it is used indiscriminately. Organic aliments show less exposure to pesticides, especially for children, which is the fact of great importance for public health, seen that various diseases were related to these agrochemicals.

\section{Conclusion}

In conclusion, based on the above data, studied vegetables do not present pesticides residues, which were already expected because of its organic and certificated origin. Among the analyzed vegetables the effectiveness of antioxidant capacity was obtained in decreasing order: broccoli, kale, cabbage and carrot. Based on obtained results, it was possible to infer that under microbiological parameter evaluated vegetables present satisfactory hygienic-sanitary quality that reflects to use organic fertilizing handling adequacy and quality of irrigation water.

\section{Acknowledgements}

The authors are thankful to FAPERJ (Fundação Carlos Chagas Filho de Amparo a Pesquisa do Estado do Rio de Janeiro) for the financial support.

\section{References}

[1] Brazil Health Ministry (2005) Secretary of Attention to Health. General Coordination of Feeding and Nutrition Policy. Dietary Guide for Brazilian Population: Motivating Health Nutrition, Sequence A, Technical Standards and Manuals, 236.

[2] IBGE. The Brazilian Institute of Geography and Statistics (2011) Brazilian Household Budget Survey 2008-2009: Nutritional Evaluation of Home Food Availability in Brazil/IBGE. Coordination of Work and Income, Rio de Janeiro, 54.

[3] IBGE. The Brazilian Institute of Geography and Statistics (2011) Brazilian Household Budget Survey 2008-2009: Analysis of Personal Food Consumption in Brazil/IBGE. Coordination of Work and Income, Rio de Janeiro, 150. 
[4] Faller, A.L.K. and Fialho, E. (2009) The Antioxidant Capacity and Polyphenol Content of Organic and Conventional Retail Vegetables after Domestic Cooking. Food Research International, 42, 210-215. http://dx.doi.org/10.1016/j.foodres.2008.10.009

[5] Brazil, National Health Surveillance Agency (2010) General Toxicological Management. Program of Pesticides Residues Analysis in Aliments (PARA)—Report of Activities in 2009, Brasília, 22 June 2010.

[6] Association of Official Analytical Chemists (1998) Official Methods of Analysis. Washington DC.

[7] Rufino, M.S.S., Alves, R.E., Brito, E.S., Pérez-Jiménez, J., Saura-Calixto, F. and Mancini-Filho, J. (2010) Bioactive Compounds Antioxidant Capacities of 18 Non-Traditional Tropical Fruits from Brazil. Food Chemistry, 121, 996-1002. http://dx.doi.org/10.1016/j.foodchem.2010.01.037

[8] Sánchez-Moreno, C., Larrauri, J.A. and Saura-Calixto, F. (1998) A Procedure to Measure the Antiradical Efficiency of Polyphenols. Journal of the Science of Food and Agriculture, 76, 270-276. http://dx.doi.org/10.1002/(SICI)1097-0010(199802)76:2<270::AID-JSFA945>3.0.CO;2-9

[9] Brand-Williams, W., Cuvelier, M.E. and Berset, C. (1995) Use of Free Radical Method to Evaluate Antioxidant Activity. LWT_Food Science and Technology, 28, 25-30. http://dx.doi.org/10.1016/S0023-6438(95)80008-5

[10] American Public Health Association (2002) Compendium of Methods for the Microbiological Examination of Foods. 4th Edition, Washington DC.

[11] Brazil, National Health Surveillance Agency (2001) Technical Regulations about Microbiological Standards for Foods. Health Ministry, Brasilia.

[12] General Inspectorate for Health Protection (1996) Analytical Methods for Pesticide Residues in Foodstuffs. 6th Edition, Ministry of Health Welfare and Sport, The Netherlands.

[13] Lehotay, S.J. (2004) Quick, Easy, Cheap, Effective, Rugged and Safe (QuEChERS) Approach for Determining Pesticide Residues. In: Vidal Martinez, J.L. and Garrido Frenich, A., Eds., Pesticide Analysis in Methods in Biotechnology, Humana Press, USA.

[14] Brazil, Brazilian Sanitary Surveillance Agency (2012) Monographs of Pesticides. http://portal.anvisa.gov.br/wps/portal/anvisa/home/agrotoxicotoxicologia/ monografiasdeagrotóxicos

[15] Bourn, D. and Prescott, J. (2002) A Comparison of the Nutritional Value, Sensory Qualities, and Food Safety of Organically and Conventionally Produced Foods. Critical Reviews in Food Science and Nutrition, 42, 1-34. http://dx.doi.org/10.1080/10408690290825439

[16] Dangour, A.D., Dodhia, S.K., Hayter, A., Allen, E., Lock, K. and Uauy, R. (2009) Nutritional Quality of Organic Foods: A Systematic Review. American Journal of Clinical Nutrition, 90, 680-685. http://dx.doi.org/10.3945/ajcn.2009.28041

[17] Dangour, A.D., Dodhia, S.K., Hayter, A., Allen, E., Lock, K. and Uauy, R. (2010) Nutrition-Related Health Effects of Organic Foods: A Systematic Review. American Journal of Clinical Nutrition, 92, 203-210. http://dx.doi.org/10.3945/ajcn.2010.29269

[18] Arbos, K.A., de Freitas, R.J.S., Sterz, S.C. and Dornas, M.F. (2010) Antioxidant Activity and Total Phenolic Contents in Organic and Conventional Vegetables. Food Science and Technology, 30, 501-506. http://dx.doi.org/10.1590/S0101-20612010000200031

[19] Prior, R.L., Wu, X. and Schaich, K. (2005) Standardized Methods for the Determination of Antioxidant Capacity and Phenolics in Foods and Dietary Supplements. Journal of Agricultural and Food Chemistry, 53, 4290-4302. http://dx.doi.org/10.1021/jf0502698

[20] Santos, G.C. and Monteiro, M. (2004) Organic System of Food Production. Alimentos e Nutrição Araraquara, 15, 7386.

[21] Mukherjee, P.A., Speh, D., Dyck, E. and Diez-Gonzalez, F. (2004) Preharvest Evaluation of Coliforms, Escherichia coli, Salmonella, and Escherichia coli 0157:H7 in Organic and Conventional Produce Grown by Minnesota Farmers. Journal of Food Protection, 67, 894-900.

[22] Altieri, M. (2002) Agroecology: Scientific Bases for Sustainable Agriculture. Agropecuaria, Gaiba.

[23] Caporal, F.R. and Costabeber, J.A. (2004) Agroecology: Some Concepts and Principals. MDA/SAF/DATER-IICA, Brasília, 24.

[24] Jardim, A.N.O. and Caldas, E.D. (2009) Chemical Dietary Exposure and the Risks to Human Health. Quimica Nova, 32, 1898-1909. http://dx.doi.org/10.1590/S0100-40422009000700036

[25] Ferreira, S.M.R., de Freitas, R.J.S., Karkle, E.N.L., Quadros, D.A., Tullio, L.T. and Lima, J.J (2010) Quality of Tomato Cultivated in the Organic and Conventional Cropping Systems. Food Science and Technology, 30, 224-230. http://dx.doi.org/10.1590/S0101-20612010000100033

[26] de Ponti, T., Rijk, B. and van Ittersum, M.K. (2012) The Crop Yield Gap between Organic and Conventional Agriculture. Agricultural Systems, 108, 1-9. http://dx.doi.org/10.1016/j.agsy.2011.12.004 
Scientific Research Publishing (SCIRP) is one of the largest Open Access journal publishers. It is currently publishing more than 200 open access, online, peer-reviewed journals covering a wide range of academic disciplines. SCIRP serves the worldwide academic communities and contributes to the progress and application of science with its publication.

Other selected journals from SCIRP are listed as below. Submit your manuscript to us via either submit@scirp.org or Online Submission Portal.
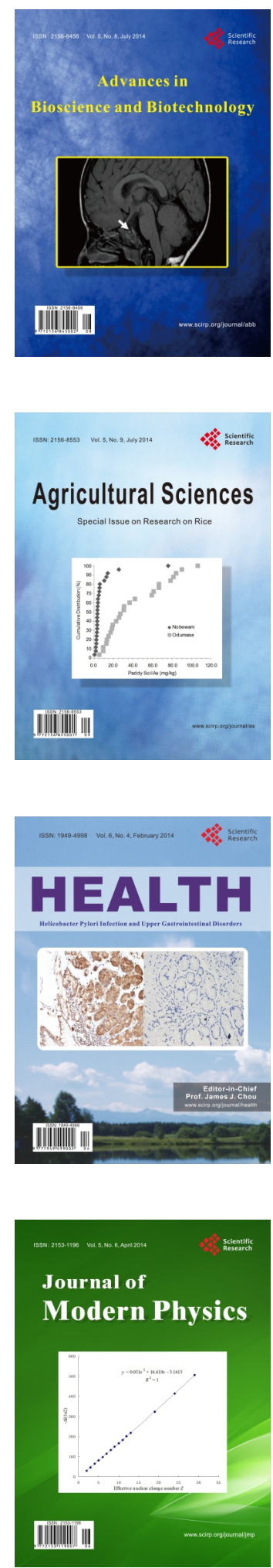
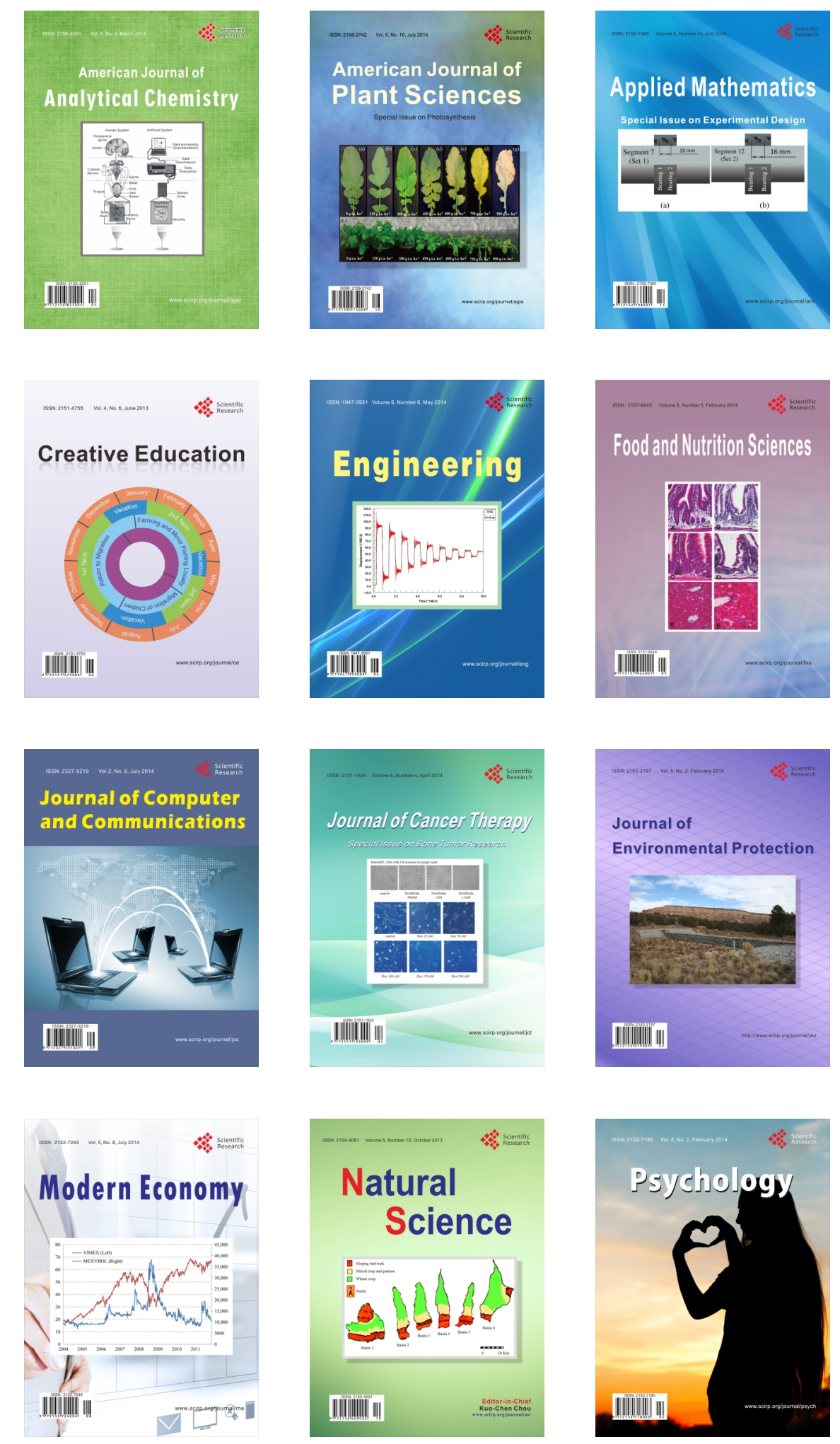